\title{
TAX REGIME AND CHALLENGES OF SCALING UP TAX COLLECTION IN NIGERIAN INFORMAL ECONOMY
}

\author{
https://doi.org/10.47743/jopafl-2021-20-17
}

\author{
Gbeminiyi K. OGUNBELA \\ Department of Public Administration, Federal Polytechnic Ilaro \\ Ilaro, Nigeria \\ gbeminiyi.ogunbela@federalpolyilaro.edu.ng \\ Oluwakayode M. AKINBOBOYE \\ Department of Public Administration, Federal Polytechnic Ilaro \\ Ilaro, Nigeria \\ Toyin L. OGUNBIYI \\ Department of Public Administration, Obafemi Awolowo University \\ Obafemi, Nigeria
}

\begin{abstract}
The vast and rapid dynamism in economic policies towards improved and speedy policy implementation aided by unrelenting technology capabilities have also transitioned into the tax administration economy. E-taxation is steadily taking the place of manual taxation. Electronic tax system expresses fast, convenient, cost efficient, organized and transparent taxation rather than tasking, time consuming and tax officials-tax payers' corruption ridden operations of manual taxation. This article, engaging exploratory-qualitative research technique, examines multinational peculiarities of automated taxation to draw lessons from issues emanating from implementation, adoption and compliance. It further shed light on challenges of migrating e-tax collection to informal economies in Nigeria. From the extant review of cross-cultural literatures, it was revealed that developed and developing countries are gradually embracing and making constant efforts towards transitioning into a more established e-tax system. Countries like USA, China, Canada, Japan, Russia, Costa Rica, Colombia, and Kenya already joined in adopting etaxation. The paper argued that inadequate database of taxable individuals; expensive internet infrastructure, cyberspace crime and limited awareness among tax payers are drawing back implementation of e-taxation in the Nigerian informal economies, and subsequently suggests practicable policy options.
\end{abstract}

Keywords: Tax policy, TIN, e-tax literature, Informal Economy, Rural Economies

\section{Introduction}

Tax is a common terminology in public finance. It has been diversely conceptualized by different authors but in substance these conceptions are resemblance of one another. According to Oseni, "Tax is a compulsory financial charge or a levy imposed upon a taxpayer by the government to fund various public expenditures for the benefits of the people" (Oseni, 2016, p. 49). Oseni (2016) further stressed that the main aim of imposing tax by the government was to procure public expenses such as cost of law enforcement, public welfare, economic infrastructure and public services, he further connoted that the words "compulsory" and "government" used above explained the legal power of government at various level to invoke punishment on the tax evaders. Though, the two terms, taxation and tax have been in existence since the emergence of public service 
in the ancient era. They are the heartbeat of revenue hub of any state as they provide assurance for financing government activities. Navigationally, tax administration as an orthodox source of revenue to government, transcended through series of reformations and restructuring. The amendments made to administration of tax policies in many developed and developing economies were to; block tax revenue leakages; increase tax net; reduce tax filling duration, encourage self-tax assessment, ensure prompt issuance of tax invoice and receipt, and attend to tax complaint (Sabitova and Khafizova, 2015; Oseni, 2016), so as to deepen the overriding principles of equity, simplicity, economy and certainty in the entire tax system. These lofty objectives invariably suggested that tax administration faces certain challenges that were needed to be tackled. Therefore, in attempt to actualize perfect, efficient, and effective tax system, most economies (developed and developing) deployed electronic automations into the tax systems. Therefore, e-tax administration is viewed by many countries as an important layer in the overall implementation and administration of their taxations and taxes respectively. Ozgen and Turan (2007) conceived it as "a new technology based system that does not necessitate for tax payers to go to tax authorities to pay their taxes due. System is composed of turning-in tax declaration forms that defines tax owned to tax authorities in an electronic format and pay taxes due via electronic environments based on internet through interactive bank accounts or by Automated Teller Machine (ATM). E-taxation is called to collect taxes by tax authorities in electronic environments via electronic declaration and electronic payment method”.

The Nigerian tax system has undergone various policy changes and evolution since its inception. Nigeria, before the adequate implementation of electronic taxation in 2016 (Fowler, 2017), the manual tax system was the mainstream of Nigerian tax administration. The manual tax administration has experienced several challenges ranging from administrative challenge, death of experienced and qualified personnel, level of corruption on the basis of tax officials collusion with would be taxpayers to defraud the government of her taxes, non-availability of database of all taxable individuals, tax touting at the level where unprofessional individuals are presented with the responsibility of collecting taxes and levies, nonpayment/delay in the payment of tax refunds. These challenges have necessitated a paradigm shift to the modern system of electronic taxation.

The introduction of electronic taxation in Nigeria was prompted by the International Monetary Fund (IMF) fiscal affairs division in 2005/2006. In 2013, the FIRS upon the approval of the Federal Executive Council introduced, procured, installed and implemented the Integrated Tax Administration System (ITAS) with the aim to enhance tax administration and simplify the tax compliance process in Nigeria through the automation of all core processes around registration, payment, assessment, debt and credit management, audit and investigation, case management band return filing with the use of technology (Deloitte, 2017). According to Fowler (2017), the FIRS adopted the ITAS in the year 2016.

Existing literature differs on contextual explanation of operational issues confronting developed and developing economies after the introduction of information technology into the administration of tax, having this in mind, this article excavated literature on the operational adaptability of e-tax administration with a view to providing fresh insight into bottlenecks contending with scaling of e-tax regimes especially at the level of rural economies in Nigeria. This paper using exploratory-qualitative research technique is designed into four sections, first is this foregoing part, then followed by an 
expansive excavation of literature on operational deployment of e-taxation from transnational perspective, the third part shed more lights on the scaling challenges in the process of diffusing automated tax administration in Nigeria to rural landscape, and in the end we proposed policy recommendations for government action.

\section{Review of e-tax literature: adoptions, operations and limitations}

In a report by Ernst and Young LLP (2016), digitization of tax system is neither the sole agenda of taxpayers nor the main responsibility of tax authorites, the report summarized that automated tax system consisted of five phases; Electronic Filing (level 1, taxpayers use electronically designed platform for filing tax returns and other income data); Electronic Accounting (level 2, tax payers submit accounting or supporting documents such trial balance and invoices to accommodate possible additions or changes); Electronic Match (level 3, tax authorities use taxpayers' source documents to match data across tax types and tax jurisdiction in real time); Electronic Audit (level 4, taxpayers' data are analyzed and cross-checked in real time environment to flag out tax fraud, unintended error as well as coagulate geographic economic ecosystem as it allows government authorities to send taxpayers electronic audit assessments); Electronic Assessment (level 5, tax authorities assess tax liability to the taxpayers without tax forms). Brondolo and Zhang (2016) noted that in China, the administration of tax was paper based and performed manually with minimal utilization of automated system in the early 1990s, they further declared that allocation huge numbers of tax officers to conduct routine compliance check (reviewing and processing of paper tax returns), error-ridden system, increasing tax dispute, tax payers information distortion and high compliance cost necessitated, since mid-1990s, the automation of tax administration in China as "the SAT made huge investments in its information technology system during the last 20 years. These investments centered on the development of two systems: (1) the China Tax Administration Information System (CTAIS); and (2) Golden Tax Project (GTP)” (Brondolo and Zhang, 2016, p.29).

For Indian, adoption of automated of tax system was gradual, "income tax e-filing was introduced in September, 2004, initially on a voluntary usage basis for all categories of income tax assessment. But from July, 2006, it was made mandatory for all corporate firms to e-file their income tax returns. Taking this process further, from assessment year 2007 to 2008, e-filing of income tax return was made mandatory for all companies and firms requiring statutory audit under section $44 \mathrm{AB}$ of Indian Income Tax Act. For all other categories of income tax assessement, which includes salaried individuals, the use of income tax e-filing service continues to be voluntary” (Ojha, Sahu \& Gupta, 2009, p.67). Sabitova and Khafizova (2015) comparatively reported year of deployment of automated filling system for personal income tax and company income tax of some developed economies as contained in the table below.

Table 1 Use of Electronic Filling of Tax

\begin{tabular}{|c|c|c|}
\hline \multirow{2}{*}{ Country } & \multicolumn{2}{|c|}{ Year of deployment } \\
\cline { 2 - 3 } & Electronic filling of company income tax & Electronic filling of personal income tax \\
\hline United Kingdom & 2004 & 2000 \\
\hline Canada & 2002 & 1993 \\
\hline
\end{tabular}




\begin{tabular}{|c|c|c|}
\hline United States & 2004 & 1986 \\
\hline France & 1991 & 2001 \\
\hline Germany & 2011 & 1999 \\
\hline Japan & 2004 & 2000 \\
\hline Russia & 2009 & 2016 \\
\hline India & 2011 & 2009 \\
\hline
\end{tabular}

Source: Sabitova and Khafizova (2015)

Sabitova and Khafizova (2015) summary of year of deployment of online filling of company income tax and personal income tax in some countries suggested that automation of tax administration have existed for more than three decades particularly in the United States. Also going by the table above, deployment of electronic platform is not new to most of the digital based economies such as Japan, Germany, United States and Canada. A number of writers have pinpointed a number of benefits associated with deployment of ICT in the administration of tax. Verily, the deployment of electronic tax system arrived with certain benefits especially in the area of blocking revenue leakages and bursting tax evasion. Oseni (2016) submitted that "ICT has brought many innovations to the administration of tax and this has invariably increased the net revenue collected. There seems to be no hiding place for tax evaders with the use of the modern tools" (Oseni, 2016, p.53). In China for instance, Brondolo and Zhang (2016) identified automated support for tax administration functions, specialized computer system for detecting and dealing with VAT invoice fraud as part of benefits of e-tax administration. He further opined that the system controls the issuance of invoices, authenticates invoices based on encoded information embedded in each issued invoice, and cross-matches seller and purchaser invoices. This position is corroborated in Lai, Siti-Normala and Ahmed-Kameel (2005) where they remarked that the e-filing system integrated tax preparation, tax filing and tax payment. With the adoption of electronic-filing system, taxpayers can electronically file income tax returns through technologies without face to face contact with tax officers. (Lai, Siti-Normala and Ahmed-Kameel, 2005).

According to Olatunji and Ayodele (2017), introduction of automated tax system aided productivity of tax officers especially in tax collection and administration. They stressed that:

- Significance of the use of IT is infinite, some of which are; facilitates a reducing in the overhead cost of managing the agencies of government responsible for tax administration, instant computation of tax liability from the use of online tax calculator, reduced cost of registering tax payers and instant generation of tax identification number, reducing in staff-taxpayers collusion as regards tax liability, reduction in fraudulent activities of tax collectors in the aspect of non-remittance of tax received from tax payers and boost the revenue of government in terms of reduction in expenses (administrative, overhead and transactional) and corrupt practices (Olaoye \&Ayodele, 2017, p.28).

Furthermore, Umenweke and Ifediora (2016) enlisted positive impact of automation of tax administration to include benefit to tax authorities and taxpayers, accessibility, time saving and convenience, early detection of errors, curbing of corrupt practices of tax authorities, availability of taxpayers' tax history for the perusal of the tax authorities and the taxpayers and enhancement of the enforcement of tax laws. The significant exodus noted in enforcement and administration of taxation and tax respectively 
from manual system to automated system by both developed and developing countries provoked research interest in e-taxation. For instance, Ozgen and Turan (2007) studied implementation of tax declaration and management system and the tax payment system via interactive internet based bank accounts in Turkey using survey research method anchored on Theory of Planned Behaviour among 130 tax practitioners in turkey. They argued that evaluation of technology acceptance levels of users was necessary for successful implementation of new technology in the tax industry.

The study stressed the important of assessing the acceptability level of stakeholders in the tax industry particularly the tax officers and tax payers who are the major operators in the new tax regime, hence, the study tested the core constructs of Technology Acceptability Model (TAM) to examine extent to which automated tax administration was accepted in Turkey, the findings show that Perceived Ease of Use (PEU), Perceived Usefulness (PU), Self-Efficacy (SE) and Internet Experience (IE) positively and significantly influence Behaviour Intention (BI) of the taxpayers when running edeclaration platform of e-taxation in Turkey. Therefore, it could be resolved that orientation of tax operators was crucial to success of effective deployment of automated tax system in Turkey. This finding however is susceptible to defeat due to the fact that the survey did not cover representative respondents as only 130 tax practitioners could not possibly represent the view of the entire stakeholders of tax administration in Turkey. This result is similar to submission of Ojha, Sahu and Gupta (2009) on study conducted to investigate the antecedents of young Indian professionals' behavioral intention (BI) to use the income tax e filing service, the result shows that antecedents of young Indian professionals' BI to use the income tax e-filing service was influenced by perceived easeof-use, personal innovativeness in information technology, relative advantage (RA), performance of e-filing service, and compatibility, though findings shows that acceptability of e-taxation among young professional was slow in India.

Using parameters such as corporate income tax, tax information exchange, use of e-invoicing, data analytics/risk engine deployed and future to examine the state of digital taxation in America, Ernst and Young LLP (2016) conducted a comprehensively study on e-taxation system of certain countries in America. In Mexico for instance, taxpayers submit electronic accounting records for each transaction, all tax returns are done electronically, e-report of relevant transactions, tax information is shared with other government agencies and other countries especially those with signed treaties. E-invoicing mandated and validated by tax authorities, digital receipts are issued, inspection and audit of tax remitted are conducted electronically and there is need to integrate pre-filling system for individual and small companies and deploy automated tax information sharing architecture especially with European countries by the end of 2017 (Ernst and Young LLP, 2016). Electronic tax administration in Panama is characterized with unique specificities. For instance, e-filing of tax returns is mandatory while e-re-filing of amended tax return is optional. Exchange of information is non-existence as e-invoicing is not captured at source. Risk assessment and data matching were given no attention in the countries, but the country is battling with restructuring toward efficiencies and less physical interaction between taxpayers and tax authorities.

Canada electronic taxation is structured in a way that e-filing is only required for corporations with Annual Gross Revenue in excess of \$1million as insurance corporations, non-resident corporations, corporation accounting in functional currency with designated 
corporations under sec 149 of Income Tax Act exempted from e-filing. At the same time, information exchange is done electronically while e-invoicing is optional. Taxpayers right of election on VAT is exercised, data analytic tools which adopt data matching technique are deployed to assess risk and compliance level in the existing e-tax system; therefore, current trends noticed in Canada on e-tax administration suggested that the use of mobile application in rendering tax information and reminder to taxpayers (Ernst and Young LLP, 2016). Furthermore, Alibasha, Kumar and Kumar (2016) recognized enhanced customer service, quick processing time, accuracy in audit trail and reduction in processing cost as the blessings brought to tax industry in Canada through automated tax system whereas challenges like delay in tax refund; unequal access to e-tax payment support architectures like debit and credit card; system errors occasioned by software malfunction; incorrect information emanated from mismatch filing of tax identification details by tax payers (Alibasha, Kumar and Kumar,2016). The profile of automated tax administration in Chile for that matter suggested that e-filing is mandated for taxpayers as from 2017, though, epayment is motivated with interest given and fine reduction to taxpayers. Automated information exchange system with foreign tax authorities was lately withdrawn toward domestic tax authorizes. Mandatory e-invoicing is demanded from 2018 but issuance of the e-invoices not considered, taxpayers are expected to send in both purchase and sale books. Massive data cross-reference technique is deployed to promote tax audit and galvanizes statistical data on tax. The current focus of digital tax administration in Chile concentrated on investing and funding e-tax administration with a view to harnessing tax audit and collection (Ernst and Young LLP, 2016). In Colombia, e-filing is mandated for certain taxpayers with deployment of online tax website while tax assessments are carried out manually. Tax and taxpayers information are exchange based on formal request. Einvoicing is optional but limited to designated taxpayers while risk engine and data matching techniques still under construction. The burning issue is on how to develop National Technology Plan by 2017(Ernst and Young LLP, 2016). Findings emanating on the status of automated tax administration in United States shown that only large business electronically file tax returns, monthly payment of tax and withholding. Tax information is carefully shared with countries with which there is existing treaties and agreement. Absent of VAT made e-invoicing non-functional but demanded during tax audit, data analytic tool is deployed to ensure compliance, risk assessment and audit selection with aid of aggregated tax information from third parties. Focusing on pre-filing tax returns; selfmanagement of account; harmonizes information from other government agencies to ascertain tax liability (Ernst and Young LLP, 2016). In Argentina, tax software and website of authorities are integrated with other government agencies whereas e-invoicing is mandatory since 2015. Matching of taxpayers data with undisclosed analytical tool is another feature identified. The major concern is an electronic tax audit and e-tax receipt (Ernst and Young LLP 2016).

Brazilian automated tax system embraces e-filing of accounting and tax books as tax information exchange among federal tax authorities especially for corporate tax is encourage while VAT information is distributed among federal and state tax authorities. E-invoicing required accounting and tax bookkeeping as well as double party validation from government (the seller validates and the buyer validates, both from government). Random selection of taxpayers based on electronic tax information for inspection is usually adopted meanwhile Brazilian government targeted improvement on integrating tax 
information on control and production of inventory and e-social program by consolidating provision of tax, social security and other employee obligations (Ernst and Young LLP, 2016). Looking ahead, Ernst and Young LLP (2016) branded inadequate format for filing tax data; hindrance in submitting data, inefficient processes; outdated operating model; inability to respond to audit notices in timely manner; not enough process support for new data requirement; inability to quickly respond to disagreement with tax assessment as the challenges upsetting e-tax administration of countries in the America continent. Dove (2008) noted that stable internet service; synergy among tax authorities, financial institutions and taxpayers; ICT compliance taxpayers; investment in automated infrastructure for tax administration; peculiar environment where digital tax administration is deployed; quality of business processes; available IT expertise determine success rate of any newly installed automated tax system. Challenges such as taxpayers' incapacity to supply electronic returns owing to legal tussle surrounding introduction of digital signature and data encryption; integrity and confidentiality of tax information; fraud risk; response rate of tax authorities and compliance issues (Edward-Dove, 2008). Dove (2008) further appreciated that though deployment of digital taxation is difficulty in some countries, its benefits surpass the tasks involved. In the beginning, adoption of e-filing and e-payment might not be hopeful but in the long run, automated tax administration minimizes cost of tax administration, increases accuracy of tax data, ensures convenience on the part of both taxpayers and tax administrators and quick collection of taxes whereas tax authorities are expected to synergize with third parties in order to attain optimal exploitation of the etaxation (Dove, 2008).

Price Waterhouse Coopers [PWC] (2017) discovered that in Africa, that there are still difficulties in paying taxes, though, the region posted highest frequency of tax payment and second highest Total Tax Rate in the globe. Time span for compliance could still be improved upon as Total Tax Rate persist to respond positively while deployment of accounting software and automated tax system increase filing and payment of tax couple with decreasing rate of time to comply, in the Asia Pacific, indicators shown that compliance interval increases as against reduction in number of payment made by taxpayers due to either deployment of electronic system or improvement in existing digital taxation (PWC, 2017) whereas Central America and the Caribbean's introduction of electronic tax architecture has improved Total Tax Rate, though, compliance issues still constitute a thorn in the flesh for the Latin Americas. In Central Asia and Eastern Europe for instance, the continue introduction of new e-tax platform and improvement of electronic system resulted into positive performance saw in the Total Tax Rate, Compliance level and frequency in tax payment recorded in the region. South America's tax system, due to certain reform in the tax industry, has improved particularly in Total Tax Rate, time to comply has also gone down, and this is not unconnected to the installation and enhancement in the electronic tax regime. Reviewing the state of automated tax system in China particularly VAT, Brondolo and Zhang (2016) were of the opinion that the deployment of automated tax system was seen by the government as vital pillar for improving the effectiveness and efficiency of tax administration in China as such governmental efforts were directed toward improving existing electronic tax system. Going forward, Brondolo and Zhang (2016) further flag off the shortcomings identified in the system to include absent of centralized databases of tax information as result lead to inability of State Administration of Taxation to "easily compile the type of national data 
that is crucial for assessing the evaluating the performance of its operational programs and field offices, conducting data mining and risk analysis, and tracking taxpayers' activities across provinces and with related entities" (Brondolo and Zhang, 2016, p.55). Other challenges affecting automation of tax administration include the need to certify and crossmatch invoices between purchasers and sellers to detect fraudulent invoices, system imposition of very high compliance costs on taxpayers, non-existence of legal mechanism for authenticating electronic invoices (i.e., an electronic signature) and technological platform to operate the system (Brondolo and Zhang, 2016).

It would not be out of order to observe that adoption and acceptability issues constituted some challenges in deploying automated tax administration in some jurisdiction. Again, in Malaysia, survey conducted among 600 tax practitioners reported strong intentions to use the e-filing system among tax practitioners, usefulness and easiness of e-filing system, time and cost saving as major drivers supporting deployment of etaxation in Malaysia. The study instigated that e-taxation guaranteed spirit of tax compliance among the tax payers except for concerns over security of online tax transactions (Lai, Normala and Kameel, 2005), still on e-tax administration in Malaysia, Doing Business (2014) as well reported that between 2006 and 2011, individuals and companies e-filing and e-payment increased from $5 \%$ to $34 \%$, the concerted strive to improve electronic tax administration in Malaysia has been easing out administrative and institutional bottlenecks embattled in the process of filing corporate tax returns (Doing Business, 2014). Record shown that time distance for filing tax returns has been in tailwind owing to improvement in e-taxation which has captured many small and medium size outlets, innovatively, tax preparers invented best spoke software that interfaced with tax authorities' e -filing portal and, again, improvement recorded in the existing digital taxation nurtured avenue for taxpayers to file tax estimate as such upward movement in general compliance is observable. Malaysia's knowledge has revealed the opportunities and challenges that information technology can provide in the tax industry (Doing Business, 2014) while deployment of electronic tax system in Costa Rica has spurred greater efficiency and effectiveness in tax collection. Standardization of the processes of e-filing of taxpayers and e-payment of tax liability significantly reduced time to comply and the number of tax payment made in the country. Digital tax administration in Costa Rica was developed in a piecemeal; introduction of electronic filing and payment for larger taxpayers; building capacity in term of skill and expertise with learning curve as exposure to practices and principles of e-taxation gather momentum; extension of coverage band to other taxpayers; enactment of law for dealing with digital signatures and e-documents; standardization of tax returns e-platform through Digital e-tax website; development of Virtual Tax Administration Portal (Luis, 2017). The innovative deployment of e-taxation made tax refund and tax assessment hitch-free, at the same time ensures that pre-filing, filing and post-filing processes of e-tax administration are less time consuming and less involving in Costa Rica. Sabitova and Khafizova (2015) review level and quality of tax administration by situating electronic tax administration in Russia in the midst of other European countries using cost of tax administration; cost structure, personal and corporate income tax returns filed through electronic means as parameters. Based on tax cost structure analysis, human resources constitute the key feature of tax administration. The worldwide practice suggests that the labor cost varies from $60 \%$ to $90 \%$ of the total tax expenditures. The average country specific labor costs are about70\% of the total tax 
administration expenditures (Sabitova and Khafizova, 2015). The study notified that highly-developed countries like US and UK where labour cost is lower than average labour cost of countries in OECD is further favoured with existence of state of art information technologies as stated here: "For the countries of OECD, the labor costs are just over those not being the OECD member, which can be explained by higher wage level in the developed economies that overweighs other tax costs in the relative measurement. However, in some highly developed countries with the labor cost much lesser than the average value, this fact is determined by higher level of information technologies that reduce the number of employees. This can be specifically seen in such countries as the UK and the USA. The IT costs in the non-OECD countries are low. This measure, however, keeps growing over the last years. Therefore, the statistical data confirm that the current tax administration is going to actively use the information technologies" (Sabitova and Khafizova, 2015, p.170).

Still locating the status of Russia tax automation regimes, personal and corporate income tax returns filed via electronic platform in non-OECD and OECD states were compared (Sabitova and Khafizova, 2015). The average data for the OECD countries show that the electronic corporate tax return is $68 \%$ in 2011 which is more compare to nonOECD countries. However, an electronic tax returns system for both the corporate income tax and other tax payments has been actively developing due to tax administration enhanced quality and expanded range of services rendered to the taxpayers in Russia. This resulted into increase in electronic tax returns and the number of taxpayers, who have a contact-free access to the tax database to check their budget settlements. Automated tax administration in Russian provided taxpayers with document providing tax, charge, fine and penalty settlements; extracts from budget settlements; a list of tax returns (settlements) and accounting statements for the report year; and a reconciliation report of tax, charge, fine and penalty settlements (Sabitova and Khafizova, 2015), the comparative analysis of tax business in different countries in terms of tax administration revealed that Russia focuses efforts on the comfort conditions for communication between taxpayers and tax authorities, It is a good practice in Russia to develop online communication of tax authorities with taxpayers, using newest information technologies in undertaking tax activities. The wide use of current information technologies enables automation of the entire process of tax administration as part of international tax cooperation, the automated Information systems are being developed that ensure tax business, facilitate communication at a quality level and exchange the information between the tax authorities worldwide. Making of such system will allow for more effective and accurate employing the information component of tax authorities. The information exchange between tax authorities in different countries should also develop to reduce double taxation significantly. Umenweke and Ifediora (2016) typified United States electronic tax system as the heartbeat of the US thriving economy as well appreciated positive possibilities of an efficient automated tax system in Nigeria. They identified convenience in proper capturing of taxable taxpayers and protection of taxpayers from the arbitrary excesses of the various tax authorities in Nigeria as added advantages for smooth running of the system while suggesting for continuous update of tax payer data base, maintenance of the existing database of taxpayers, specific tax laws should be enacted at the federal and state levels to properly give legality to the e-taxation process and full implementation (no option for 
manual filing) of e-taxation for Federal, State and Local government taxes (Umenweke and Ifediora, 2016).

OECD's survey report on the trend of issues on adoption of e-service for taxpayers in European economies revealed collection of e-platforms for tax administration solutions. E-tax websites embedded with user friendly features enable taxpayers to enjoy many options of tax activities and access to immense tax data such as Virtual Tax Assistant deployed in Slovenia, Generic E-Mailing and Telephony E-Tax Service, this supported penetration of multiple e-tax payment solution (like Direct Debit, Direct Credit). Deviation from unique standard of E-filing of tax returns exposed some European countries to limited benefit of automated tax administration. Routine information exchange (tax bulk data) is allowed among government agencies for broader utilization. The components of taxpayers' bulk data in most European countries included conventional tax information and data for matching of other governmental e-services such as social welfare program, vehicle registration and tax information while selective but strictly limited access to NonGovernmental Organization (OECD, 2010). In the developing countries like Kenya, Wasao (2014) reported that generally, taxpayers in all sectors accepted online tax system involving online registration, online filling and online payment that makes recruitment of taxpayers easy and hence tax compliance is achieved among taxpayers in Nairobi, this position was previously upheld in Eva (2010), it was argued that easy registration significantly enhanced compliance among tax payer in Kenya. Meanwhile, Bird (2015) believed that consideration should not be given only to revenue generated through tax collection, but also to apt information requires to deepening principle of certainty in tax administration, hence, the essence of ICT deployment in administration of tax as automated tax administrative structure smokes out unnecessary, unused, unedited taxpayers information and the same time mopped out effective risk management strategies for effective and efficient tax management system (Bird, 2015). This view articulated cost benefit analysis, risk management and information management system as contending issues in tax administration in the developing countries, though, Nigerian e-tax administration is scheduled to undergo reform tagged "a revolution in tax administration in Nigeria" by Nigerian Federal Inland Revenue Service, this is expected to reflect trends in global digital tax system. Guardian Newspapers (2017) reported that "the Federal Inland Revenue Service (FIRS) has introduced six key electronic solutions (e-Services) to enhance convenience, transparency and round the clock processing and payment of taxes payment: e-TaxPay, Remita); receiving of electronic receipt after payment of taxes (through eReceipt); filing tax returns online (through e-filing) and online Tax Clearance Certificates (TCC) through electronic Tax Clearance Certificate (e-TCC solution)". This move by the service is long overdue but efforts should be directed to challenges dreading current status of e-taxation administration in Nigeria, in the next section, attention is shifted to understand the vitiating bottlenecks contending with scaling of e-tax regimes at the level of rural economies.

\section{Nigerian informal economy: challenges of scaling up e-tax collection}

The use of e-taxation in Nigeria focused on six procedures including electronic registration, Tax Identification Number (TIN) verification and issuance, electronic filing of tax returns, tax payment, electronic confirmation issuance, and tax refunds (Umenweke 
and Ifediora, 2016).Despite efforts made by Nigeria towards an effective electronic tax system, it is still notwithstanding conceived to lack infrastructure and expertise in enforcing these programs or maybe tax payers were hesitant to make full use of online capabilities (PWC and World Bank Group, 2013). In Okifo and Igburu (2015) view, Nigeria has two types of e-payment namely: the end-to-end processing where all transactions are carried out electronically and the manual e-payment which is a mixture of manual and electronic processes as a result of available infrastructures' incapability of accommodating end-toend processing. It was thus concluded that the electronic tax scheme in Nigeria still remains a manual e-payment. In defining Informal Economy (IE), tax authorities and researchers have used different criteria ranging from the number of employees, to the location, size of the shape, number of transactions, low barrier to entry, ownership structure and legal status has been used to define IE (Cole and Fayissa, 1991, Ebifuro et al, 2016). In Nigeria, IE refers to any business operating outside the control of government regulation (Magbagbeola, 1996; Adesanya, 2014). A few number of these businesses function within the sphere of the small scale enterprise, which popularly lack precise locations due to the constant mobility nature of the businesses. This consequentially makes these businesses activities difficult to regulate, secure and locate, thus presenting an uphill task to governmental tax officials in their efforts to oversee these small scale enterprise operations (Adesanya, 2014; Akenbor and Arugu, 2014; Akintoye and Tashie, 2013).

The International Labour Organisation (ILO) grouped the IE into two namely: the coping strategy and the unofficial earning strategy. The first group which is the coping group expresses the series of tasks people engage in for survival, such as: temporary occupations, small commercial farming, and hawking, to name a few, while the unofficial earning group encompasses business activities targeted towards tax avoidance, shunning tax rules and regulations. They therefore neglect the legal requirement of business registration with established and authorized agencies.

The Informal Economy engages business operations lacking its ambience within the legal framework and formal configuration (ILO, 2002). Schneider et al. (2010) was of the opinion that majority of the businesses currently recognized in the formal sector (and now pay taxes) originally began in the informal economy having experienced series of growth and expansion. However, reverse is the case in some nations with fast paced growth in the informal economy when compared with the formal sector of the economy. This resulted from the IE flexibility, structure, low entry level and ease of operation (Ibadin and Eiya, 2013; Ilaboya, 2012) as opposed to the high unemployment rate and poor performance of the formal sector in Nigeria (Olaoye et al., 2009; Ohaka and Zukbee, 2015), the IE has thus served as a mode of survival as people now engage in small scale business activities (Ademu, 2006; Oko and Omini, 2014), including a large number of people employed in the formal sector (Igbeng et al., 2012; Umoru and Anyiwe, 2013). The informal economy includes: hawking, events planning business, make-up artists, roadside food vendors, cab operators, small scale farming, and couture.

Evidently, majority of the economy has diversified into the uneasy to tax informal economy because of the ease and fluidity of operating them. The Small and Medium Scale Enterprises Development Agency of Nigeria (SMEDAN) study discovered that $80 \%$ of businesses operate within the Micro, Small and Medium-size Enterprises (MSMEs) which submits that $75 \%$ of Nigerians are actively employed. According to Adesanya (2014), Micro Enterprises comprise of 98\% of the Micro, Small and Medium-size Enterprises. 
However, 1\% of each of these Micro Enterprises is associated to SMEs. Although, the reasonability of categorizing these businesses as formal economy would have been easily actualized, but due to lack of regulation, unrefined and malformed nature of the informal economy, this feat has remained imaginary. Among various challenges experienced in the Nigerian e-taxation system includes the plagues of interrupted internet access, interrupted power supply basically recognized by the FIRS as the primary challenges of e-filing especially in rural areas where majority of a large number of the prospective taxpayers reside and work with difficult terrain and pay no tax at all on their earnings. Although, a few others who are identified under direct assessment and minimum tax payers on some earnings but failed to declare other additional sources of income majorly classified and recognized as an informal economy and classified as Personal Income Tax.

Previous studies have revealed that of all the taxes, personal income tax has remained the most disappointing, non-performing, unsatisfactory and problematic in Nigeria tax system (Asade, 2005; Kiabel and Nwokah, 2009; Nzetta, 2007). A large number of these personal income earners reside and work in the rural areas. The peculiar nature of rural communities require that government should be up and doing in providing for public good and infrastructure in this area. In the Nigerian context, rural communities are characterized by poor infrastructure development, bad road networks and neglect in the provision of basic amenities including basically pipe-borne water, electricity, schools and health care services. As observed by Schneider and Klinglmair (2004); and Schnider et al (2010), in many developing economies (Nigeria inclusive), the informal sector contributes a large proportion of revenue which represents significant source of growing share of the Gross Domestic Product (GDP). Due to the dwindling oil revenue arising from the fall in oil prices across the globe and the weak value of Naira, the Nigerian economy has been subjected to an unstable state, the view of taxing the informal sector firms may therefore become necessary in sustaining tax morale and compliance among larger entities (Almet et al., 2013; Torgler 2003). Thus, the need to study the likely challenges threatening the migration of electronic tax system in the informal sector becomes important and relevant. The non-availability of database of taxable individuals is one major challenge confronting the implementation of e-tax system in informal economic sector of rural areas. This is due to non-registration of businesses in the informal economy in a bid to avoid tax. This is made possible by the untraceable, unregulated and unstructured nature of the informal economy. This poises an obstacle for relevant tax authority in obtaining a database for assessment as it must first establish the residence of the taxpayers. Informal sector operatives are those persons who blatantly refused to pay tax and reporting losses every year (Kiabel and Nwokah, 2009).

Poor internet/ cellular connectivity and high rate of cyber fraud are other impediments confronting the implementation of electronic tax collection in the informal sector. Owners of businesses would rather choose to collect real cash before customers leave with their purchased items. This results from lack of reliability of the internet and cellular networks in providing quality on online payment platforms leaving traders with the uneasiness of contacting (at their own cost) their commercial institution(s) for payment confirmation, while waiting days before payment is eventually effected. Also, high rate of cyber crime, fraudulent activities and distrust in online payment platforms originating from day to day cyber fraud methods of operation. These challenges have incapacitated tax authorities in analyzing the range of business transactions and detecting the magnitude of 
businesses through electronic payments which could have provided a concrete basis of evidence for account auditing. Tax authorities are faced with the difficulty of keeping business transactions audit trail in the informal economy due to lack of online payment and poor accounting.

The first phase and requirement towards e-taxation is the registration phase which is undoubtedly made possible by the existence of IT system. The challenge of inadequate and unreliable power (electricity) supply has restricted MSMEs especially in rural settlements from registering into the e-tax system due to the need for electricity in operating the IT system. The lack of power supply coupled with insecurity and inadequate infrastructural amenities which are the needs of the people are left unattended to majorly at the rural economy. Business owners and employees are therefore left with the sole responsibility of meeting these needs; in most cases avoid tax payment. They argue that they see no justification to pay their tax when the government has equally failed to provide infrastructural amenities. The rural business owners simply believe tax payment in unbeneficial and they are thus discouraged from the payment of taxes. Furthermore, the unawareness of existing e-taxation system due to the limited access of the rural settlers to adequate and timely information. Majority of rural business owners are still left in the dark, while some are misinformed on the benefits of e-taxation by fellow local dwellers and corruptible tax officials. This challenge restricts them to continuing in the primitive manual taxation system on one hand. On the other hand, some business owners in rural economy are ignorant and remained uneducated on the benefits of regular tax payment to the government and the community at large.

IT illiteracy is another major factor challenging the development of e-taxation in rural communities. Majority of rural business owners are not exposed to the proper operation of technological devices. This causes a blockage in their advancement into the application of an automated mode of tax payment. Setting up of e-tax registration and epayment centers in these communities would have provided a lasting solution to this challenge, unfortunately, another impending block is the fear of insecurity of taxpayers' data. Tax payers are afraid to release their data details as these details can be used to access other online payment platforms, taxpayers account information, funds and consequentially become victims of cyber fraud. Therefore, taxpayers would rather embrace and continue with the manual tax system. In addition, the cost of initiation of e-taxation is very high and this can discourage or delay its initiation in rural communities. This challenge is further fostered by the inadequate existence of technological structures which could ease and aid speedy implementation.

In conclusion, e-taxation is an indispensable and effective tool for transforming tax administration and fostering national development. Although faced with varieties of challenges, the positive attributes of e-taxation overshadows the negative challenges confronting its implementation.

\section{Submission and policy options}

Tax has served as a contributor to countries Gross Development Product, states IGR, and also poses as a veritable tool for economic development and economic sustainability. However, much focus has been placed on the implementation of tax policies majorly on the organized, easy to access and easy to tax formal sector of the economy. 
Consequentially, and as exposed by recent researches, the informal economy is vast and fast growing; motivated by its flourishing, unorganized, easy to run and difficult to tax nature in developing countries, with little attention and concern to its keen capability of contributing to the country's economy in a noticeable extent. The informal economy, although located in cities and rural economies, several obstacles have been encountered in its administration and implementation of tax policies, especially with the transition from manual tax system to the electronic/technological tax system. The challenge of implementing the new e-tax system is however predominant within the rural economies primarily due to lack of existing tech-friendly structures. This study therefore proposed the following recommendations with an effort towards tackling the implementation challenges of e-taxation in the informal sector with special focus on the rural economies.

In point of fact, tax authorities such as the SMEDAN, the government or newly established agency/agencies on tax matters should be saddled with the responsibilities of investigating the activities of MSMEs in Nigeria with the purpose of capturing and registering tax payers in the informal sector into the tax net as well as ensuring their data base are accurate and up to date. This will help increase government's accessibility of tax payers in the informal economy and subsequently promote seamless taxation among SMEs and improve the nation's GDP. The government should endeavor to improve on the provision of social amenities and engage in empowerment plans that are beneficial to everyone. This factor will bring relief to the peoples' financial burden as they will need not to solely incur the costs of power, security, expensive health care, inaccessible educational policies. Also, they will be encouraged to pay their taxes voluntarily as they will feel more cared for by the government, as they can see what they have paid for being put in place and adequately functioning for their convenience.

Furthermore, an upgrade of data management systems and security of tax payers' data will help increase the ease of e-registration, e-filing, e-payment and e-refund. This can be achieved via the implementation of reliable internet/cellular connectivity, and taking advantage of the modern cyber security methods to address security challenges on the online platforms that will help build taxpayers confidence in the e-taxation system. In addition, several devices (e.g. IOS, Android, Microsoft) compatible platforms should be put in place and easily accessible by tax payers. These platforms will create a room for the submission of complaints and get communicated by tax authorities. These platforms can also help in reminding tax payers of their tax payment due dates. Public establishments and mediums such as radio, TV, adverts in different dialects aimed at creating awareness on the new e-taxation system, the benefits of paying taxes, tax laws and sanctions for tax evasion and avoidance should be put in place.

The recommendations stated above re-emphasized the position of Efunboade (2014) stated that the introduction of tax week, filing tax returns, tax counseling, establishing tax electronic management system, regular auditing and examination, penalty provisions, tax education are capable of improving the satisfactory level of revenue in developing countries through self-assessment. Similarly, Okello, (2014) identified education, provision of service oriented attitude, enacting stringent deterrents to noncompliance, regular auditing and transparency on the part of government and tax authority will enhance voluntary compliance capable of improving revenue generation. Finally, the mixed method of integrating manual tax system and e-taxation should be applied in the tax 
administration scheme so as to provide tax payers with a backup plan for manual filing in the event of glitches in the electronic taxation system.

\section{References}

1. Ademu, W. A. (2006). The informal sector and employment generation in Nigeria: The role of credit. In Annual Conference of the Nigerian Economic Society (NES). pp. 22-24.

2. Adesanya, B. (2014). Informal Economy Survey Report. Philip Consulting. November 2014. pp. 136. Available at: https://phillipsconsulting.net/reports_post/informal-economy-survey/

3. Akenbor, C. O. and Arugu, L. O. (2014). State government taxation: Empirical evidence from Nigeria. The Business Management Review 4(3):63-71.

4. $\quad$ Alibasha, S.M., Kumar, J.K., and Kumar, N. (2016). Benefits and Challenges of E-Filing and E Payments. International Journal of Commerce, Business and Management, 5(4), 71-75.

5. Bird, R. M. (2015). Improving Tax Administration in Developing Countries. Journal of Tax Administration, 1(1), 23-45.

6. Brondolo, J. and Zhang, Z. (2016). Tax Administration Reform in China: Achievement, Challenges and Reform Priorities. International Monetary Fund Working Paper, WP/16/68.

7. Cole, W. E. and Fayissa, B. (1991). The urban subsistence labour force: Toward a policy- oriented and empirically accessible taxonomy. World Development 19(7):779-789. https://doi.org/10.1016/0305750X(91)90132-2

8. Deloitte (2017). Nigeria: FIRS Introduces six electronic services. Monday Advice centre in Association with ICSA. Retrieved from www.Mondaq.com/2018.

9. Doing Business (n.d). Implementing Election Tax Filing and Payment in Malaysia. Retrieved from www.doing business. org/-/media/WBG/Doing Business/Documents/annual report/DB14/Implementingelection-tax-filing.pdf

10. Ebifuro, O, Mienye E, and Odubo, T. V. (2016). Application of GIS in Improving Tax Revenue from the Informal Sector in Bayelsa State, Nigeria. International Journal of Scientific and Research Publications 6(8):1-13.

11. Edwards-Dove, D. (2008). E-Filing and E-Payments: The Way Forward. Being Paper Presented at Caribbean Organization of Tax Administration (COTA) General Assembly, Belize, July, 2008.

12. Efunboade, A. O. (2014). Impact of ICT on Tax Administration in Nigeria.Computer Engineering and Intelligent Systems, 5(8): 26-29.

13. Ernst and Young (2016). Tax Administration is Going Digital: Understanding the Challenges and Opportunities. Retrieved from www.ey.com/publication/vw LUA Assest/EY-tax administration-is-goingdigital.

14. FIRS Introduces Six Online Tax Solutions. (2017, June 5). The Guardian Newspaper.

15. Fowler, B. (2017, April). FIRS to expand automated tax administration. Retrieved from https://www.vanguardngr.com/2017/04/firs-expand-automated-tax-administration/

16. Ibadin, P. O., and Eiya, O. (2013). Tax Evasion and Avoidance Behaviour of the Self-Employed Nigerians. European Journal of Business and Management 5(6):1-16.

17. Igbeng, E., Tapang, A.T. and Usang O. U. E. (2012). Analysis of tax morale and tax compliance in Nigeria. European Journal of Business and Management 4(14):182-207.

18. Ilaboya OJ (2012). Indirect Tax and Economic Growth. Research Journal of Finance and Accounting 3(11):70-82.

19. IMF (2011) 'Revenue Mobilization in Developing Countries, Washington DC: International Monetary Fund (http://www.imf.org/external/np/pp/eng/2011/030811.pdf>

20. Kiabel, B.D. and Nwokah, G. N. (2009). Boosting revenue generation by state governments in Nigeria: the tax consultant option revisited. European journal of social sciences-volume 8 , November 4 .

21. Lai, M., Siti-Normala, O., and Ahmed-Kameel, M. (2005). Tax Practitioners and The Effect of Electronic Filing System: An Empirical Analysis. Academy of Accounting and Financial Studies Journal, 9(1), 93-109.

22. Luis, D. B. (2016). Digital Innovation to Increase Voluntary Complaince. In PWC (Ed.) Paying Taxes 2017. Retrieved from www.pwc.com/gx/en/paying taxes/pdf. 
23. Magbagbeola, N. O. (1996). The role of the informal sector in Nigeria "s post-adjustment economy. In Nigerian Economic Society, Beyond Adjustment: Management of the Nigerian Economy. Selected Papers of the 1996 Annual Conference of the Nigerian Economic Society. pp. 263-272.

24. OECD (2010). Survey of Trends and Development in the Use of Electronic Service for Taxpayers Service Delivery: Final Report. Retrieved from www.oecd.org/ctp/treaties/1923272/pdf.

25. Ohaka, J. and Zukbee, J. D. (2015). Taxation and Sustainable Development in Nigeria: Informal Sector Challenges. Research Journal of Finance and Accounting 6(10):249-252.

26. Ojha, A., Sahu, G. P., and Gupta, M. P. (2009). Antecedents of Paperless Income Tax Filing by Professional: An Explorating Study. Transforming Governmnet: Peeple, Process amd Policy, 3(1), 65-90. doi: 10.1108/17506160910940740.

27. Okello, A. (2014).Managing income tax compliance through self-assessment” IMF working paper No. $14 / 41$.

28. Okifo, J. \& Igbunu, R. (2015). Electronic payment system in Nigeria: Its economic benefits and challenges. Journal of Education and practice, 6(16), 56-62.

29. Oko, I. E. and Omini, E. E. (2014). Tax Innovation, Administration and Revenue Generation in Nigeria: Case of Cross River State. International Journal of Social, Education, Economics and Management Engineering 8(5):1579-1576.

30. Olaoye C. O., Asaolu, T.O. and Adewoye, J. O. (2009). Review of Revenue Generation in Nigeria Local Government : A Case Study of Ekiti State. International Business Management 3(3):54-60.

31. Olatunji, O. C. and Ayodele, K. B. (2017). Impact of Information on Tax Administration in Southwest, Nigeria. Gblobal Journal of Management and Business: (D) Accounting and Auditing, 17(2), 25-33.

32. Oseni, M. (2016). Sustanance of Tax Administration by Information and Communication Technology in Nigeria. Business Research, 4(1), 47-54. doi:1014738/abr.41.1734.

33. Ozgen, F. B., and Turan, A. H. (2007). Usage and Adoption of Online Tax Filing and Payment System in Tax Management: An Empirical Assessment with Technology Acceptance (TAM) Model in Turkey. Being Paper Presented at the 9th International Scientific Conference Organized by Vytautus Magnus University, Kaunas, 27th September, 2007 28th September, 2007.

34. PWC (2016). Paying Taxes 2017: Final Report. Retrieved from www.pwc.com/gx/en/paying taxes/pdf.

35. Sabitova, N. M., and Khafizova, A. R. (2015). Information Technologies as a Factor of Evolution of Tax Administration. Mediterranean Journal of Social Science, 6(1), 169173. doi:10.5901/mjss.2015.v6n1s3p169.

36. Schneider, F., Buehn, A., and Montenegro, C. E. (2010). Shadow Economies All over the World: New Estimates for 162 Countries from 1999 to 2007. Policy Research Working Paper 5356. pp. 1-48. Available at: https://openknowledge.worldbank.org/bitstream/handle/10986/3928/WPS5356.pdf?seque nce $=1$

37. Torgler, B. (2003). Theory and empirical analysis of tax compliance.Basel: University of Basel.

38. Umenweke, M. N., \& Ifediora, E. S. (2016). The law and practice of electronic taxation in Nigeria: The gains and challenges. Nnamdi Azikiwe University Journal of International Law and Jurisprudence, 7, 101-112.

39. Umoru, D., and Anyiwe, M. A. (2013). Tax Structures and Economic Growth in Nigeria: Disaggregated Empirical Evidence. Research Journal of Finance and Accounting 4(2):65-79.

40. Wasao, D. (2014). Effect of Online Tax System on Tax Compliance among Small Taxpayers in East of Nairobi Tax District. Unpublished M.Sc. Thesis, Department of Finance and Accounting, University of Nairobi, Nairobi, Kenya.

41. World Bank and PWC (2013). Paying taxes report. World Bank Group. Retrieved from www.PWC.com/gx/end/payingtaxes/PDF/. 


\section{(c) (i) $(9)$}

EY NC ND This article is an open access article distributed under the terms and conditions of the Creative Commons Attribution - Non Commercial - No Derivatives 4.0 International License. 